\title{
Surface circulation in the Eastern Mediterranean using drifters (2005-2007)
}

\author{
R. Gerin ${ }^{1}$, P.-M. Poulain ${ }^{1}$, I. Taupier-Letage ${ }^{2}$, C. Millot $^{2}$, S. Ben Ismail ${ }^{3}$, and C. Sammari ${ }^{3}$ \\ ${ }^{1}$ Istituto Nazionale di Oceanografia e di Geofisica Sperimentale (OGS), Borgo Grotta Gigante, 42/c, 34010 Sgonico, \\ Trieste, Italy \\ ${ }_{2}^{2}$ Université de la Méditerranée, Laboratoire d'Océanographie Physique et de Biogéochimique (LOPB), CNRS UMR 6535, \\ Antenne de Toulon, BP 330, 83507 La Seyne, France \\ ${ }^{3}$ Institut National des Sciences et Technologie de la Mer (INSTM) - 28, rue du 2 mars 1934, 2025 Salammbô, Tunisia
}

Received: 2 February 2009 - Published in Ocean Sci. Discuss.: 6 March 2009

Revised: 28 August 2009 - Accepted: 25 September 2009 - Published: 10 November 2009

\begin{abstract}
Within the framework of the EGITTO/EGYPT programs, the spatial structure and the temporal variability of the surface circulation in the eastern basin of the Mediterranean Sea was studied with satellite-tracked drifters. A total of 97 drifters drogued to $15-\mathrm{m}$ nominal depth were released between September 2005 and March 2007, regularly along ship-of-opportunity routes in the Sicily Channel and within specific structures during dedicated campaigns in the Levantine sub-basin. This study complements previous ones in the former and in the Ionian, but it is the first one in the latter. After editing and low-pass filtering, the drifter trajectories were used to estimate pseudo-Eulerian statistics: mean current, variance ellipses, mean and eddy kinetic energies. A statistical analysis was also performed dividing the dataset in two extended seasons (winter and summer). A branching behaviour of the surface water after passing through the Sicily Channel is evidenced, together with a seasonal variability inducing a reversal of the circulation in the southern part of the Ionian. In the Levantine, the surface circulation describes an eastward flow along the Libyan and Egyptian slopes (the Libyo-Egyptian Current: LEC) that continues in a cyclonic circuit along the Middle East and Turkish slopes. This general alongslope circuit can be perturbed locally and temporally by the numerous anticyclonic eddies that co-exist in the Levantine, mainly created by the instability of the LEC in the south (Libyo-Egyptian Eddies: LEEs), but also by the wind (Ierapetra and Pelops), and by the topography (over the Eratosthenes Seamount and off Latakia). The most frequent perturbation is the entrainment of part of the flow seaward: the LEEs close to the slope can interact with the LEC, which
\end{abstract}

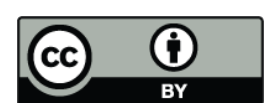

Correspondence to: R. Gerin (rgerin@inogs.it) then spreads more or less around them, so that a series of contiguous LEEs (paddle-wheel effect) can possibly result in an eastward offshore transport (the so-called Mid Mediterranean Jet). Additionally, when LEEs are close enough to the slope, most of the surface flow is spread seaward. Along the slope the current is then induced by the LEEs southern side which results in a westward current. Locally and temporally the circulation along the slope can thus be reversed.

\section{Introduction}

The surface circulation in the eastern basin of the Mediterranean Sea is principally that of the water of Atlantic origin (AW): we do not differentiate the various types of AW specified in the literature. Several maps of the surface circulation in the basin have been presented throughout the years (see the successive representations in Hamad et al., 2005). However consensus has yet to be achieved, especially in the southern part of the basin. The surface circulation was described for the first time by Nielsen (1912) who used hydrographic data from the Danish cruise onboard R/V Thor (1908-1910) and hypothesised that a major role was played by the Coriolis effect, resulting in a cyclonic circulation around the whole basin. Other descriptions of this circulation, inferred from geostrophic computations of more substantial hydrographic datasets, were proposed subsequently. Ovchinnikov (1966) suggested a circulation displaying several closed circuits in both the southern Ionian and the area between $20^{\circ} \mathrm{E}$ and $36^{\circ} \mathrm{E}$ that, in the following, will be called the Levantine subbasin (see Fig. 1 for the geographical references), and noted some seasonal variability in the circulation patterns. Lacombe and Tchernia (1972) described a flow of AW entering

Published by Copernicus Publications on behalf of the European Geosciences Union. 


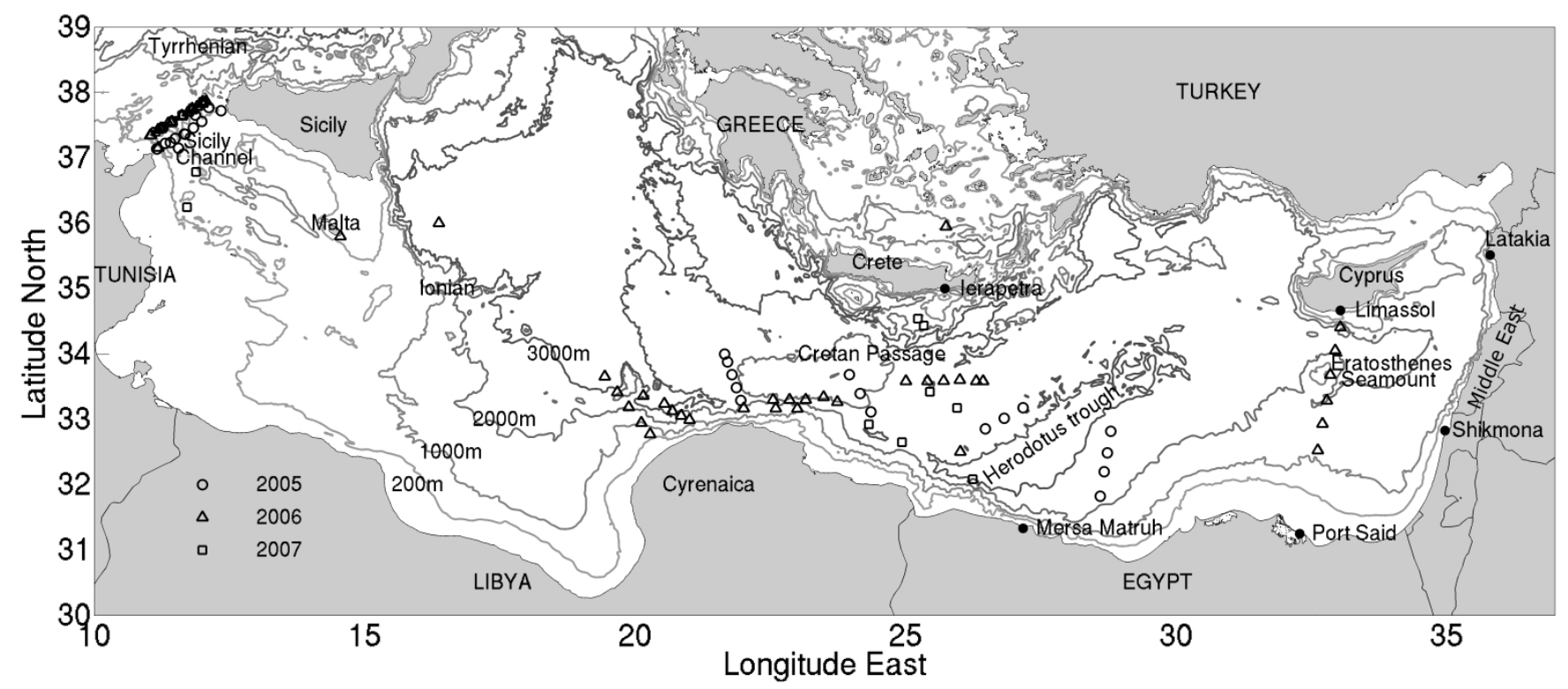

Fig. 1. Eastern Mediterranean area $\left(30^{\circ}-39^{\circ} \mathrm{N}, 10^{\circ}-37^{\circ} \mathrm{E}\right)$ with geographical names and sites of drifter deployment (coded per year). The area between $20^{\circ} \mathrm{E}$ and $36^{\circ} \mathrm{E}$ is denoted as the Levantine sub-basin. The $200 \mathrm{~m}, 1000 \mathrm{~m}, 2000 \mathrm{~m}$ and $3000 \mathrm{~m}$ isobaths are represented in grey tones.

the Sicily Channel, crossing the Ionian north of two anticyclonic circuits and reaching Libya near $20^{\circ} \mathrm{E}$. From there, the authors represented the flow spreading toward the open sea, so that near $25^{\circ} \mathrm{E}$ it extends from the Libyo-Egyptian coast as far as south of Crete. The surface water cyclonic circuit is depicted continuously at the basin scale. Additionally, all these historical diagrams show a cyclonic circulation in the northern Ionian.

Studies performed in 1985-1992 during the international program Physical Oceanography of the Eastern Mediterranean (POEM) issued a different description. Robinson et al. (1991) suggested a schema in which the main feature in the Levantine is a cross-basin current that they named the Mid Mediterranean Jet (MMJ). This MMJ is depicted crossing northeastward from $\sim 24^{\circ} \mathrm{E}$ to southeast of Cyprus, and bifurcating to delineate circulation features such as "Mersa Matruh" and "Shikmona". There is no surface flow along Africa. This schema was detailed later (Robinson and Golnaraghi, 1993; Malanotte-Rizzoli et al., 1997) in the Ionian: the flow of AW, named the Atlantic Ionian Stream (AIS) in the Sicily Channel, is depicted meandering and bifurcating east of Sicily. A central branch is represented crossing the Ionian, while the northern branch extends up to $40^{\circ} \mathrm{N}$ before turning southward and joining the central branch offshore Libya near $20^{\circ} \mathrm{E}$, thus describing an anticyclonic circuit in the northern part of the Ionian, which is a reversal of the circulation in contrast to the previous schema. This anticyclonic circuit was also indicated by Mauerhan (2000) using drifter data in the period 1986-1999 and Lermusiaux and Robinson (2001) during the summer of 1996.
A few years ago, the circulation of the basin was studied using 4-year time series of satellite infrared images and reinterpreting all available in situ observations. The resulting new schema (Hamad et al., 2005, 2006; Millot and TaupierLetage, 2005) depicts a cyclonic circulation all around the basin (roughly as in historical representations) that is mainly constrained along the upper part of the continental slope. In the south, surface water flow, called the Libyo-Egyptian Current (LEC), is unstable and generates anticyclonic eddies (Libyo-Egyptian Eddies: LEEs) evolving in time and space. These LEEs have diameters of 100-150 km, lifetimes of several months (up to more than one year), and propagate downstream (eastward) along the slope at $1-3 \mathrm{~km} / \mathrm{d}$. They strongly modify the structure of the LEC, which can result in advecting surface water offshore. Other anticyclonic eddies induced by the northerly Etesian winds off Ierapetra and Pelops (IE and PE, respectively in Fig. 2) have been shown to possibly propagate even far away from their generation area, have lifetimes exceeding one year and therefore possibly coexist, in particular for IE, with the newly-generated eddies (e.g. Hamad et al., 2006; Taupier-Letage, 2008). "Mersa Matruh" and "Shikmona" are no longer described as permanent or recurrent eddies, but as areas where (anticyclonic) eddies tend to accumulate and/or merge. These authors explained that the so-called MMJ was actually the part of the flow carried offshore around the (successive) northern edges of both the eddies generated by the LEC and IE, and disconnected from the main alongslope path (POEM only sampled offshore and did not considered the historical data available to the south). 


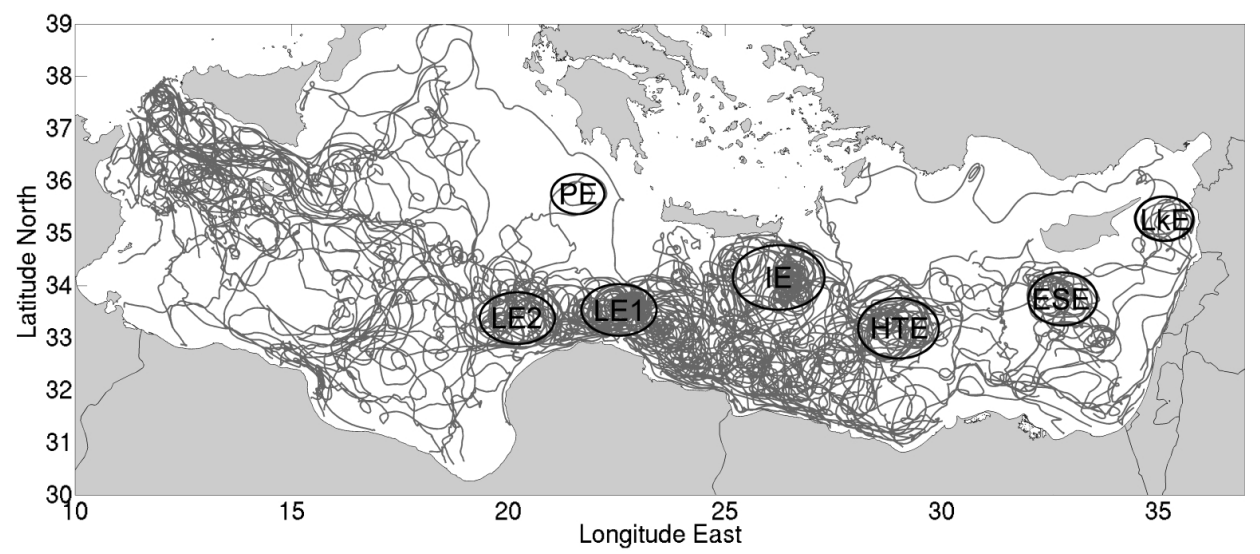

Fig. 2. Edited drifter trajectories from deployment to 31 October 2007 and locations of the major sub-basin eddies analyzed: Pelops Eddy (PE), Libyan Eddies (LE1 and LE2), Ierapetra Eddy (IE), Herodotus Trough Eddy (HTE), Eratosthenes Seamount Eddy (ESE) and Latakia Eddy (LkE).

The main path of AW along the Libyo-Egyptian slope is supported by other recent works. For example the numerical simulations by Korres and Lascaratos (2003) show during summertime a coastal current (that is yet called MMJ), and those from Alhammoud et al. (2005) depict all year long the existence of an alongslope basin-scale cyclonic circulation with no evidence of a permanent offshore path. Studies using satellite altimetric data (Rio et al., 2007) and in situ XBT data from 1 year-long repeated transects (Fusco et al., 2003; Zervakis et al., 2003) also reach the same conclusion about the permanency of the alongslope main flow.

The scarcity of in situ observations in the southernmost parts of the basin (see e.g. Fig. 2 of Manca et al., 2004) is one of the reasons for the discrepancies of the surface circulation schemas. Therefore, to investigate the circulation (at all levels) and the role of the eddies in perturbing the general circulation, a joint effort was initiated, involving teams from Italy (OGS: EGITTO program, http://doga.ogs.trieste. it/sire/drifter/egitto_data.html), France (LOB and LOCEAN: EGYPT program, http://www.ifremer.fr/lobtln/EGYPT/) and Tunisia (INSTM). The EGITTO/EGYPT programs included, during 2005-2007, surface drifters and Argo profiling floats, a network of moorings, hydrographic surveys, remote sensing measurements and numerical simulations (see TaupierLetage et al., 2007; Beranger et al., 2007). One of the main goal was to study the surface circulation of the Eastern Mediterranean with particular focus on the Sicily Channel and the southern part of the Levantine. In this paper, we present the results of the investigation of the spatial and temporal variability of the surface circulation in the basin using satellite-tracked drifters. The drifters and their deployment strategy are described in Sect. 2, together with information on the database, the methodology used to process the data and on the mean wind pattern in the studied area. PseudoEulerian maps of the mean flow, eddy variability and energy levels are presented in Sect. 3. The whole dataset is first con- sidered and then it is divided in two extended seasons to explore the seasonal variability. The results are discussed and summarized in Sect. 4.

\section{Data and methods}

\subsection{Drifter characteristics}

The drifters used in this study are the mini WOCE-SVP (model CLEARSat-15) manufactured by Clearwater Instrumentation. For details on the WOCE-SVP design, see Sybrandy and Niiler (1991) and Lumpkin and Pazos (2007). The surface buoy is tethered to a cylindrical drogue (with a 60-cm diameter and a 5-m height), centred at a nominal depth of $15 \mathrm{~m}$. The buoy is equipped with a sea surface temperature sensor and a tension sensor that allows checking the presence of the drogue. All drifters were tracked with the Argos Data Location and Collection System carried by the NOAA and METOP polar orbiting satellites. This system provided about nine locations/d with accuracy better than $1000 \mathrm{~m}(\mathrm{Ar}-$ gos User's Manual, $2008^{1}$ ).

\subsection{Strategy of deployments}

A total of 97 drifters were deployed between September 2005 and March 2007 in the basin (Fig. 1 and Table 1). In the Sicily Channel and in the Ionian a seasonal variability was expected. As a result, the deployments were organized on a seasonal basis (approximately every three months). Five to six drifters were released across a transect at the entrance of the channel, both from research vessels (R/V Hannibal and R/V Urania) and from ships of opportunity (ferries). In the Levantine, no clear seasonal signal was expected from historical measurements and wind data to dictate periodic

\footnotetext{
${ }^{1}$ Available at: https://www.argos-system.org/manual/whnjs.htm.
} 
Table 1. Details on the drifter deployment episodes in the eastern basin of the Mediterranean Sea (see Fig. 1 for the geographical references): date, location and name of the experiment, name of the ship involved and number of drifters deployed by institute.

\begin{tabular}{|c|c|c|c|c|c|c|}
\hline Date & Location & $\begin{array}{c}\text { OGS } \\
\text { drifters }\end{array}$ & $\begin{array}{c}\text { LOB } \\
\text { drifters }\end{array}$ & $\begin{array}{c}\text { INSTM } \\
\text { drifters }\end{array}$ & Experiment & Ship \\
\hline Sep 2005 & Sicily Channel & 2 & - & 4 & Transect & Medmar ferry and R/V Hannibal \\
\hline Nov 2005 & Levantine sub-basin & 15 & - & - & EGITTO-1 & R/V OGS-Explora \\
\hline Nov 2005 & Sicily Channel & 6 & - & 1 & Transect & $\mathrm{R} / \mathrm{V}$ Hannibal and R/V Urania \\
\hline Feb 2006 & Levantine sub-basin & - & 10 & - & EGYPT-0 & $\mathrm{R} / \mathrm{V}$ L'Atalante \\
\hline Feb 2006 & Sicily Channel & 6 & - & - & Transect & Grandi Navi Veloci ferry \\
\hline Apr 2006 & Levantine sub-basin & 15 & 4 & - & EGYPT-1 & R/V Poseidon \\
\hline May 2006 & Sicily Channel & 6 & - & - & Transect & Grandi Navi Veloci ferry \\
\hline Oct 2006 & south of Cyprus & 6 & - & - & EGITTO-2 & Princessa Marissa \\
\hline Oct 2006 & Sicily Channel & 6 & - & 1 & Transect & Grandi Navi Veloci ferry \\
\hline Jan 2007 & Sicily Channel & 6 & - & - & Transect & Grandi Navi Veloci ferry \\
\hline Mar 2007 & Sicily Channel & 6 & - & - & Transect & Grandi Navi Veloci ferry \\
\hline Mar 2007 & Cretan Passage & 6 & - & - & EGYPT-2 & R/V Le Suroit \\
\hline
\end{tabular}

releases. The drifters were deployed in this area (Fig. 1) mainly from ships of opportunities (transiting to Port Said), and thus the strategy was constrained by the limited shiptime available (EGITTO-1 cruise on R/V OGS-Explora in November 2005 (Poulain et al., 2006); EGYPT-0 cruise on R/V L'Atalante in February 2006; EGYPT-2 cruise on R/V Le Suroît in March 2007). Whenever possible, the strategy focused on the sub-basin circulation features identified a priori from satellite thermal images and altimetry, as in the case of the dedicated campaign EGYPT-1 (R/V Poseidon in April 2006). Thus the drifters were mostly deployed during transects across two LEEs (LE1 and LE2), IE and one eddy over the Herodotus Trough between $28-30^{\circ} \mathrm{E}$ (HTE, see Figs. 1 and 2). This latter has not been tracked yet: it may either be a LEEs or be an old IE. Finally, six drifters were also released from a ferry between Limassol (Cyprus) and Port Said (Egypt): EGITTO-2 cruise on Princesa Marissa in October 2006.

\subsection{Data and processing}

Among the 97 drifters deployed, 5 stopped transmitting immediately after deployment and were lost, while 8 were recovered and redeployed (hence being considered as new drifters). We thus obtained 100 individual trajectories that provide a database extending from 5 September 2005 to 31 October 2007 and covering the southern half of the basin (Fig. 2).

Drifter raw data were edited for outliers and spikes with automatic and manual techniques using criteria based on maximum distance, maximum speed and maximum angle between two consecutive points, as described in Poulain et al. (2004). Edited positions were interpolated at 2-h intervals with a kriging optimal interpolation schema (Hansen and Poulain, 1996). The interpolated positions were then lowpass filtered using a Hamming filter with cut-off period at 36-h to eliminate high frequency current components (tidal and inertial currents) and were finally sub-sampled at 6-h intervals. Velocity components were then estimated from centred finite differences of the 6-h sub-sampled positions.

About $40 \%$ of the observations were collected by drifters which had lost their drogues (see statistics in Table 2). In order to use the maximum number of observations for the computation, undrogued drifter data can be corrected using linear regression models of the differences between nearly collocated and co-temporal undrogued and drogued drifter velocities as a function of wind (Poulain et al., 1996, 2009; Pazan and Niiler, 2001). In particular, in this paper, we performed such a correction using the formulation introduced by Poulain et al. (2009) deduced from the present EGITTO/EGYPT database and wind products from the European Centre for Medium-range Weather Forecast (ECMWF).

Following the method detailed in Poulain (2001) and Emery and Thomson (2004), we computed the pseudoEulerian statistics to describe the surface circulation in the basin. Kriged sub-sampled data were grouped into $0.5^{\circ} \times 0.5^{\circ}$ bins, organized on a grid with $0.25^{\circ} \times 0.25^{\circ}$ mesh size to smooth spatially the results. Bins with less than 10 observations and containing data from less than two different drifters were rejected for the computation of the statistics.

Poulain et al. (2009), proved that the magnitude of the wind-driven currents in the eastern basin of the Mediterranean Sea is about $0.7 \%$ and $2 \%$ of the wind speed for the drogued and undrogued SVP drifters, respectively. Therefore, to further minimize the effect of the wind speed on the undrogued drifters, we discarded in the pseudo-Eulerian statistics the undrogued observations with a speed ratio (wind-induced slip/drifter speed) larger than $50 \%$, corresponding to an insignificant $(0.7 \%)$ reduction of the dataset. 

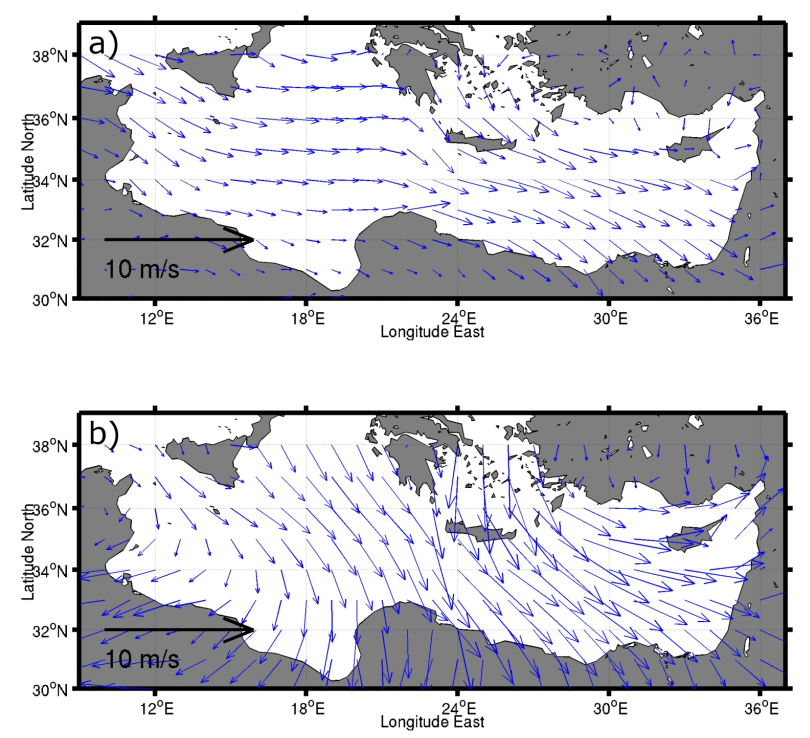

Fig. 3. Maps of the mean wind vectors for the extended winter 2005-2006 (a) and for the extended summer 2006 (b).

Trajectories outside the basin (i.e. north of Sicily) were not considered. Kinetic energy per unit of mass was computed and considered as the sum of two terms: the mean kinetic energy of the mean flow per unit of mass (MKE) and the mean kinetic energy of the fluctuations per unit of mass, also called eddy kinetic energy (EKE). The definitions of these statistics can be found in the Appendix A.

Additionally, to investigate the seasonal variability, including the possible reversal of the mean circulation in some areas, the pseudo-Eulerian statistics were also split in two extended seasons: the winter from November to April and the summer from May to October. This separation captures most of the seasonal variability, as already shown by Poulain and Zambianchi (2007) in the Sicily Channel. A statistical analysis of temperature profiles (CTDs and XBTs) available in the NODC-OGS dataset (http://nodc.ogs.trieste.it/) allowed checking that, in the basin, these extended winter and summer seasons correspond to the most homogeneous and stratified conditions of the water column, respectively.

\subsection{Mean wind pattern}

ECMWF wind products with $0.5^{\circ}$ resolution were averaged in two periods (November 2005-April 2006 and May 2006October 2006) so as to obtain the maps of the mean wind vectors for the extended winter 2005-2006 (Fig. 3a) and the extended summer 2006 (Fig. 3b). Mean winds are stronger in summer but the variability is larger in winter. There is no significant change of wind prevailing direction in the Levantine. In contrast, in the Ionian, in winter the prevailing winds are from west, while during summer they turn to north or even east. Additionally, the wind products were interpolated at the low-pass filtered drifter position so as to relate
Table 2. Mean half life (MHL), maximum lifetime and total drifterdays for all the drifters and for the drogued and undrogued drifters. The relative percentage of undrogued drifter data is about $40 \%$.

\begin{tabular}{llll}
\hline & MHL & $\begin{array}{l}\text { Max } \\
\text { lifetime } \\
\text { (d) }\end{array}$ & $\begin{array}{l}\text { Total of } \\
\text { drifterdays }\end{array}$ \\
\hline All & 108 & 348 & 11377 \\
Drogued & 62 & 271 & 6747 \\
Undrogued & 53 & 292 & 4630 \\
\hline
\end{tabular}

the drifter velocities to the local wind speed and use the correction formula suggested by Poulain et al. (2009) for the undrogued drifters. The pseudo Eulerian statistics were calculated over separated wind regimes in the Ionian where the dominant winds are the Mistral and the Scirocco. Drifters velocities were sorted into opposite wind conditions: Mistral (northwest sector) and anti-Mistral (southeast sector) winds and drifter data with associated wind speed lower than $3 \mathrm{~m} / \mathrm{s}$ were not considered.

\section{Results}

\subsection{Total dataset}

The temporal distribution of the data (Fig. 4) reveals a saw tooth shape due to the limited operational lifetime of the drifters and to the successive deployments, with strong rises in correspondence to the major deployment episodes (e.g., the EGITTO-1 cruise in November 2005, with 19 drifters released). The maximum number of drifters operating simultaneously occurred on April 2006 with 37 units. The drifter lifetime in the basin is shorter than the nominal value (autonomy of the battery) because of the high probability of stranding or being caught by seafarers. The maximum lifetime is about one year and the mean half-life, that is the time after the deployment for which $50 \%$ of the drifters still provide useful data, is more than 100 days (see Table 2).

The drifter trajectories are illustrated for each deployment episode over an arbitrary time period allowing the best visualization of the main circulation features (Fig. 5). Fortytwo drifters were released across the Sicily Channel during seven deployment episodes (Table 1 and Fig. 5a-g). The majority of the drifters entered immediately the basin (34 over 42). However, northwestward motions to the Tyrrhenian were observed for 4 deployment episodes, especially in October 2006 ( 2 out of 6 drifters, Fig. 5e) and in January 2007 ( 3 out of 5 drifters, Fig. 5f). The initial trajectories of the drifters in the channel are highly variable. They can display loops that are either anticyclonic, mainly in its northern part or cyclonic, mainly in its southern part. 


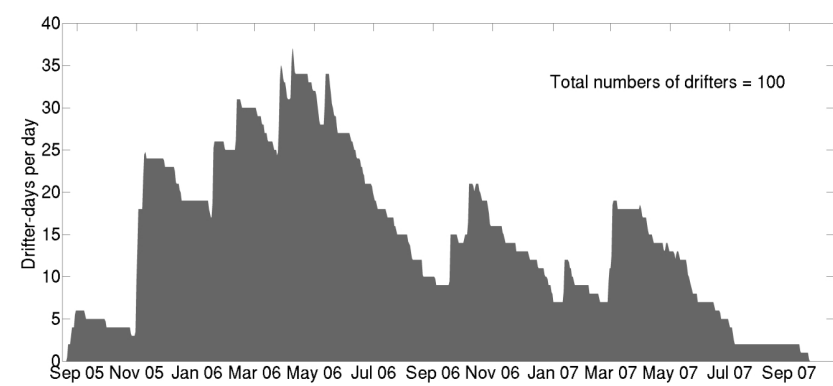

Fig. 4. Temporal distribution of the drifter data in the basin. Number of drifterdays per day from 5 September 2005 to 31 October 2007. The maximum number of drifters operating simultaneously occurred on 24 April 2006 (37 units).

East of $20^{\circ}$ E, the striking features (Fig. 5i-1) are the anticyclonic loops (especially in November 2005 and April 2006), due to the strategy of seeding drifters along transects crossing the main anticyclonic eddies: LE1, LE2, IE05 (the Ierapetra eddy resulting from the summer 2005) and HTE. The six drifters released south of Cyprus (Fig. 5h) evidenced the Eratosthenes Seamount Eddy (ESE) and additional eddies, then moved eastward and were trapped in the Latakia Eddy (LkE). Note that there are many other eddies, but only those with a long lifetime that could be tracked have been named.

From November 2005 to April 2006 LE1 and LE2 have drifted westward. By April 2006 both eddies are also closer to the coast. The westward drift of LE1 can be tracked until summer 2006 (Fig. 5k), but its tracking with thermal images shows that LE1 continued at least until the end of 2006 (Taupier-Letage, 2008; Sutyrin et al., 2009). During the winter 2005-2006, IE05 remained south of Crete. IE05 was seeded in April 2006, and the detailed trajectories of the drifters trapped inside (not shown) indicate that it first moved to the southeast, and then merged with the IE06 (the merging took a few days to complete, see Taupier-Letage 2008). The loops, curves and sharp bends of the trajectories indicate the presence of other eddies like south of HTE on Fig. 5i and $\mathrm{k}$ (red and blue tracks, respectively) and between $23^{\circ} \mathrm{E}$ and $25^{\circ} \mathrm{E}$ on Fig. $5 \mathrm{j}$ (yellow, green and blue trajectories). The trajectories of the drifters released in the southernmost region, when not in an eddy close to the slope, show an eastward current along the upper part of the slope, identified by the 200$\mathrm{m}$ isobath between LE2 and LE1, between $\sim 23^{\circ} \mathrm{E}$ and $25^{\circ} \mathrm{E}$ and $\sim 28^{\circ} \mathrm{E}$ on Fig. 5i (blue, green and orange/red trajectories, respectively), from $\sim 21^{\circ} \mathrm{E}$ up to $27^{\circ} \mathrm{E}$ on Fig. $5 \mathrm{j}$ (blue and orange), between $23-27^{\circ} \mathrm{E}$ on Fig. 51 (blue and red). Interactions between eddies and the LEC are well evidenced by the trajectory of the southernmost drifters on $\sim 23^{\circ} 30^{\prime} \mathrm{E}$ and $\sim 28^{\circ} \mathrm{E}$ in Fig. $5 \mathrm{i}$ (green and orange tracks, respectively), that of the drifter bending sharply offshore near $\sim 27^{\circ} \mathrm{E}$ in Fig. $5 \mathrm{j}$ (red) and those of the two drifters veering eastward inshore at $\sim 23^{\circ} \mathrm{E}$ and $24^{\circ} \mathrm{E}$ in Fig. 51 (blue and red, respectively).
A striking feature is the large number of trajectories crossing the basin between the Libyo-Egyptian slope and Crete, especially for the drifters that are entrained first around LE2 and LE1 and then around IE05, and then, for some, back to the southern slope. There are only a few trajectories in the easternmost part of the basin. The majority follows the upper part of the slope (which is supported by the high number of drifters stranded along the southern shores), but four drifters reached the Middle East slope by an offshore meandering route. These individualized trajectories do not evidence any offshore continuous zonal feature, and are best visualized with the movie on http://doga.ogs.trieste.it/doga/ sire/egitto/database_egitto/movies/sep05-oct07.avi.

In order to delineate the areas characterized by strong currents we plotted the drifter trajectories corresponding to lowpass filtered velocities larger than $30 \mathrm{~cm} / \mathrm{s}$ (Fig. 6). Maximum velocities are mainly recorded in the central part of the Sicily Channel and southeast of Sicily, and along the Libyan slope, in the southern Ionian. In the Levantine, they are observed in correspondence to the Libyo-Egyptian slope ( $\sim 200 \mathrm{~m}$ isobath), all the way to the Middle East. Maximum velocities also underline the position of the main eddies, especially when drifters were trapped inside (LE2, LE1, IE and HTE) and evidence the importance of the eddy activity, as for instance with the offshore velocity maxima between HTE and ESE.

However, care must be taken when considering composite figures (either by overlay or averaging) since features vary markedly in both space and time. For example LE1 and LE2 have close but distinct signatures: the drifters entrained offshore around LE2 come back southward to the slope before continuing south of LE1 or offshore around it (Fig. 5j). But when plotting their drift in time (e.g. in Fig. 6), between $\sim 20-24^{\circ} \mathrm{E}$ it looks like there is only one large feature, with that on its northern side offshore there is a quasi-continuous eastward current.

The drifter trajectory composite map (Fig. 2) and the distribution of the number of observations per bins (Fig. 7a) reveal that, generally, the spatial drifters coverage is good in the southern area of the eastern basin of the Mediterranean Sea, except in the southern Ionian and between $30^{\circ} \mathrm{E}$ and $35^{\circ} \mathrm{E}$. In the Sicily Channel and in the Levantine between $20^{\circ} \mathrm{E}$ and $30^{\circ} \mathrm{E}$, the dataset is dense and the number of observations in $0.5^{\circ} \times 0.5^{\circ}$ bins is larger than 300 .

The mean surface flow is depicted in Fig. 8a. The overall circulation is quite complex. This map shows a current entering the Sicily Channel and flowing eastward mainly on the Sicilian side. It passes between Sicily and Malta and splits into two branches upon entering the Ionian. One branch goes to the north, reaching $39^{\circ} \mathrm{N}$, before veering to the south. The other one crosses the Ionian generating a large anticyclonic loop centred at $\sim 15^{\circ} \mathrm{E}, 34 \mathrm{~N}$ and joins the previous branch in the central Ionian, at $\sim 19^{\circ} \mathrm{E}$. Along $12^{\circ} \mathrm{E}$ and $19^{\circ} \mathrm{E}$, the current is southward and reaches the Libyan coast. The flow in the southern Ionian is not well defined, especially in its 

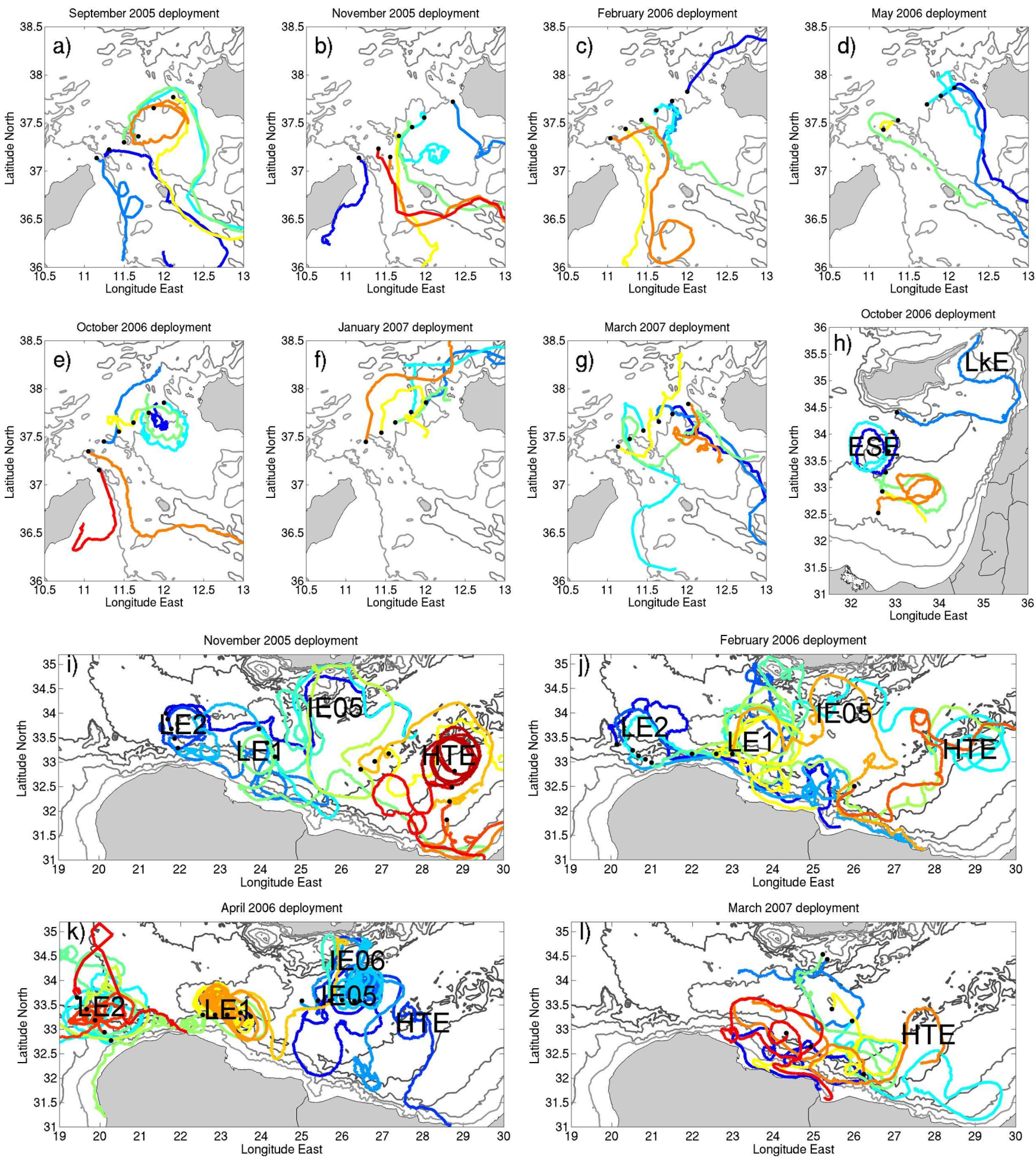

Fig. 5. Edited drifter tracks for each deployment, with deployment positions (black dots). The $200 \mathrm{~m}, 1000 \mathrm{~m}, 2000 \mathrm{~m}$ and $3000 \mathrm{~m}$ isobaths are represented in grey tones. (a)-(g) Sicily Channel: September 2005, November 2005, February 2006, May 2006, October 2006, January 2007 and March 2007 deployments, respectively; (h) South of Cyprus: October 2006 deployments; (i)-(l) Levantine sub-basin: November 2005, February 2006, April 2006 and March 2007 deployments, respectively. The duration of the tracks is chosen to represent at best the eddies and other circulation features referred to in the text. 


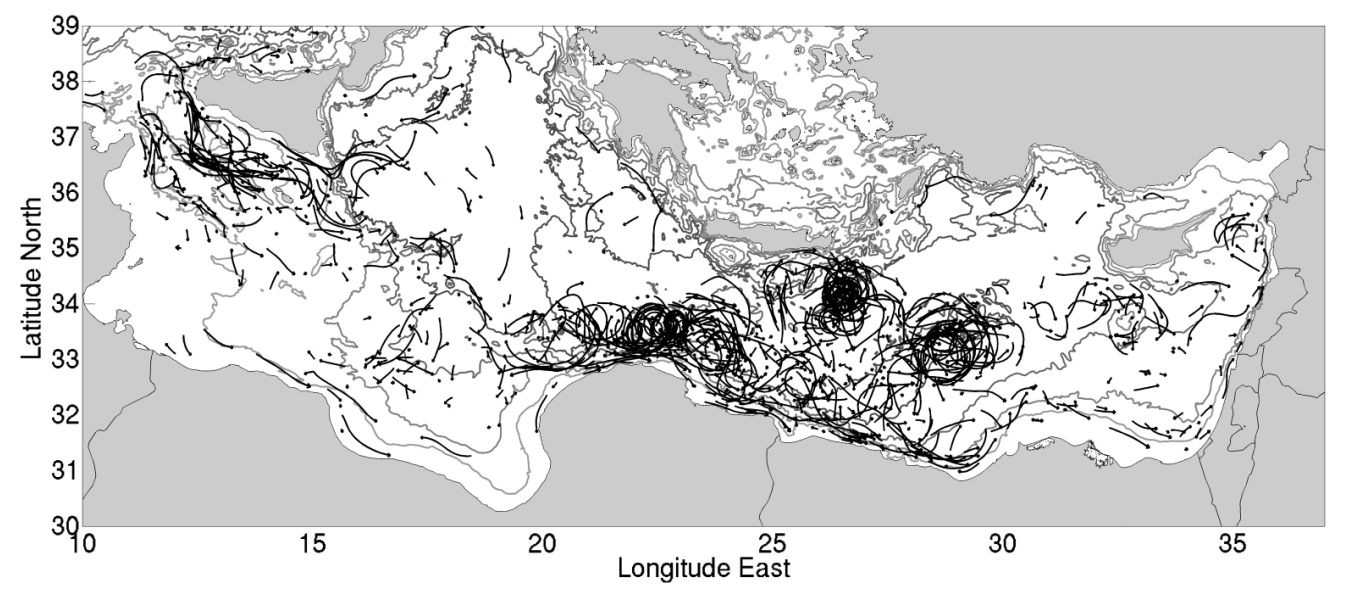

Fig. 6. Segments of low-pass filtered drifter trajectories characterized by speeds larger than $30 \mathrm{~cm} / \mathrm{s}$. The $200 \mathrm{~m}, 1000 \mathrm{~m}, 2000 \mathrm{~m}$ and $3000 \mathrm{~m}$ isobaths are represented in grey tones. Arrow heads indicate the flow direction.

southeasternmost part where there are only a few drifter observations. The signal can be considered significant only between $14^{\circ} \mathrm{E}$ and $16^{\circ} \mathrm{E}$, where the number of observations increases (Fig. 7a).

The statistics do not show a clear continuity of the flow from the Ionian to the Levantine at $19-20^{\circ} \mathrm{E}$. From $\sim 20^{\circ} \mathrm{E}$ to $23^{\circ} \mathrm{E}$, there is no definitive LEC along the slope. It appears east of $23^{\circ} \mathrm{E}$ and continues in a cyclonic circuit off the Middle East coast. The statistical results show an offshore eastward flow starting between $\sim 20^{\circ} \mathrm{E}$ and $23^{\circ} \mathrm{E}$, that meanders along $\sim 34^{\circ} \mathrm{N}$. At $\sim 24^{\circ} \mathrm{E}$, this flow appears to split. A first branch joins the alongslope LEC, either near $23^{\circ} \mathrm{E}$ or between $25^{\circ} \mathrm{E}$ and $27^{\circ} \mathrm{E}$. The second branch is sharply deflected towards Crete, around IE, and then continues eastward driven, successively, by the northern edges of HTE and ESE.

This paddle-wheel effect generated by the eddies can be seen superimposing the trajectory of the drifters on contemporaneous SST satellite images. For example, Fig. 5 of Taupier-Letage (2008) shows the trajectory of one drifter launched close to the slope near $\sim 22^{\circ} \mathrm{E}$ diverted offshore around LE2, and then crossing the Levantine sub-basin offshore (light blue trajectory on Fig. 5i). The meanders of the trajectory match the northern edge of successive eddies evidenced by the SST images.

The energy level analysis reveals that large values of MKE (Fig. 9a) are prevailing in the Ionian, in correspondence to the flow crossing this sub-basin, the northward branch northeast of Sicily and the circuit centred at $\sim 15^{\circ} \mathrm{E}$. Large values also occur off Libya, between $20^{\circ} \mathrm{E}$ and $24^{\circ} \mathrm{E}$, along the slope east of $23^{\circ} \mathrm{E}$ and in ESE and LkE. MKE is maximum in IE and HTE, where values exceed 600 and $800 \mathrm{~cm}^{2} / \mathrm{s}^{2}$, respectively, and close to PE where the absolute maximum (greater than $1000 \mathrm{~cm}^{2} / \mathrm{s}^{2}$ ) is computed.
The variance ellipses (Fig. 10a) show that along the continental slope, at basin-scale, the ellipses are generally flattened with the principal axis parallel to the slope. In the open Levantine, the ellipses are more isotropic, indicating that the fluctuating currents occur in all directions. At $\sim 25^{\circ} \mathrm{E}$, the principal axes are oriented north-south as far as Crete, as well, but to a lesser extent, along $31^{\circ}$ E. The EKE (Fig. 11a) is maximum in correspondence to PE, LE1, LE2, IE (where the absolute maximum can be found) and HTE eddies as well as along the slope between $20^{\circ} \mathrm{E}$ and $30^{\circ} \mathrm{E}$.

\subsection{Seasonal variability}

The low-pass filtered trajectories (Fig. 7b-c) divided by extended seasons reveal that the geographical coverage is broader in winter. However, the Sicily Channel, the central Ionian and the Levantine between 20 and $30^{\circ} \mathrm{E}$ are well covered in both seasons. The northern Ionian is mainly covered in summer, while the easternmost Levantine is mainly sampled during winter.

The data densities, in the well covered areas of Fig. 7a, are similar for both seasons (not shown), but it is important to note that the extended summer results are mainly due to the drifters operated during the summer 2006 (see the temporal distribution of the data, Fig. 4). For both extended seasons, the number of observations per bin is maximum (about 200 observations) in the Sicily Channel (due to the seasonal deployments), off Cyrenaica and in the main anticyclonic eddies in which drifters remained entrapped and looped several times. IE is well represented in the mean flow maps of both extended seasons (Fig. 8b-c). Its signature is less intense in winter only because in summer several drifters were released inside this eddy and re-circulated, while during winter drifters were entrained only around it. LE1 and LE2 were tracked during the year 2006 and it was checked that they moved westward, along the slope, between $20^{\circ} \mathrm{E}$ and $24^{\circ} \mathrm{E}$. 

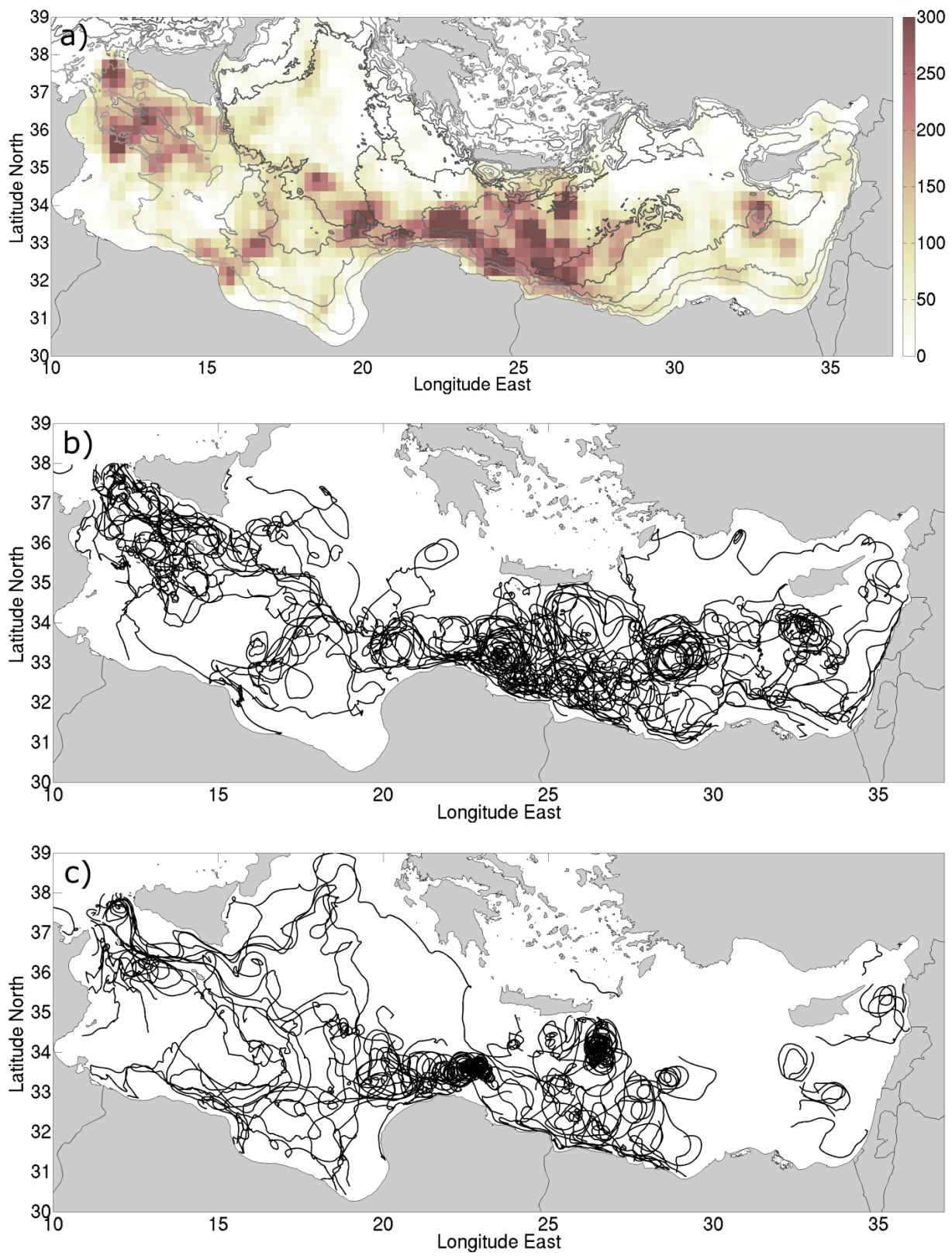

Fig. 7. Data density and drifter trajectories. (a) Data density computed with the entire dataset (saturated at 300 observations per bins). The $200 \mathrm{~m}, 1000 \mathrm{~m}, 2000 \mathrm{~m}$ and $3000 \mathrm{~m}$ isobaths are represented in grey tones. (b) Low pass filtered drifter data for the extended winter. (c) Low pass filtered drifter data for the extended summer.

HTE is localized at the offshore end of the Herodotus trough and during summer at least two other eddies co-existed in the same vicinity between $27^{\circ} \mathrm{E}$ and $30^{\circ} \mathrm{E}$. Finally, ESE and LkE are depicted in both seasons. During winter (Fig. 7b), one drifter delineates $\mathrm{PE}$ near $37^{\circ} \mathrm{N}, 21^{\circ} \mathrm{E}$ and another one identifies the cyclonic circuit south of Turkey.

The mean flow during winter (Fig. 8b) shows that the AIS entering the Sicily Channel is oriented toward southeast. Three branches can be recognized. The northern one remains parallel to the Sicily coast and enters the central Io- nian between Sicily and Malta. The central branch meanders more southward until it joins the northern one (at $\sim 35^{\circ} \mathrm{N}$ and $\sim 16^{\circ} \mathrm{E}$ ) and then reaches Libya at $19-20^{\circ} \mathrm{E}$. The third branch flows along the Tunisian shelf, far from the coastline, since the shelf is wide there. In the southern Ionian the spatial coverage is too scarce to infer a general pattern. However, an eastward current is suggested alongslope and the trajectories perpendicular to the coast are portions of anticyclonic loops localized between $14^{\circ} \mathrm{E}$ and $17^{\circ} \mathrm{E}$ and between $16^{\circ} \mathrm{E}$ and $20^{\circ} \mathrm{E}$. 

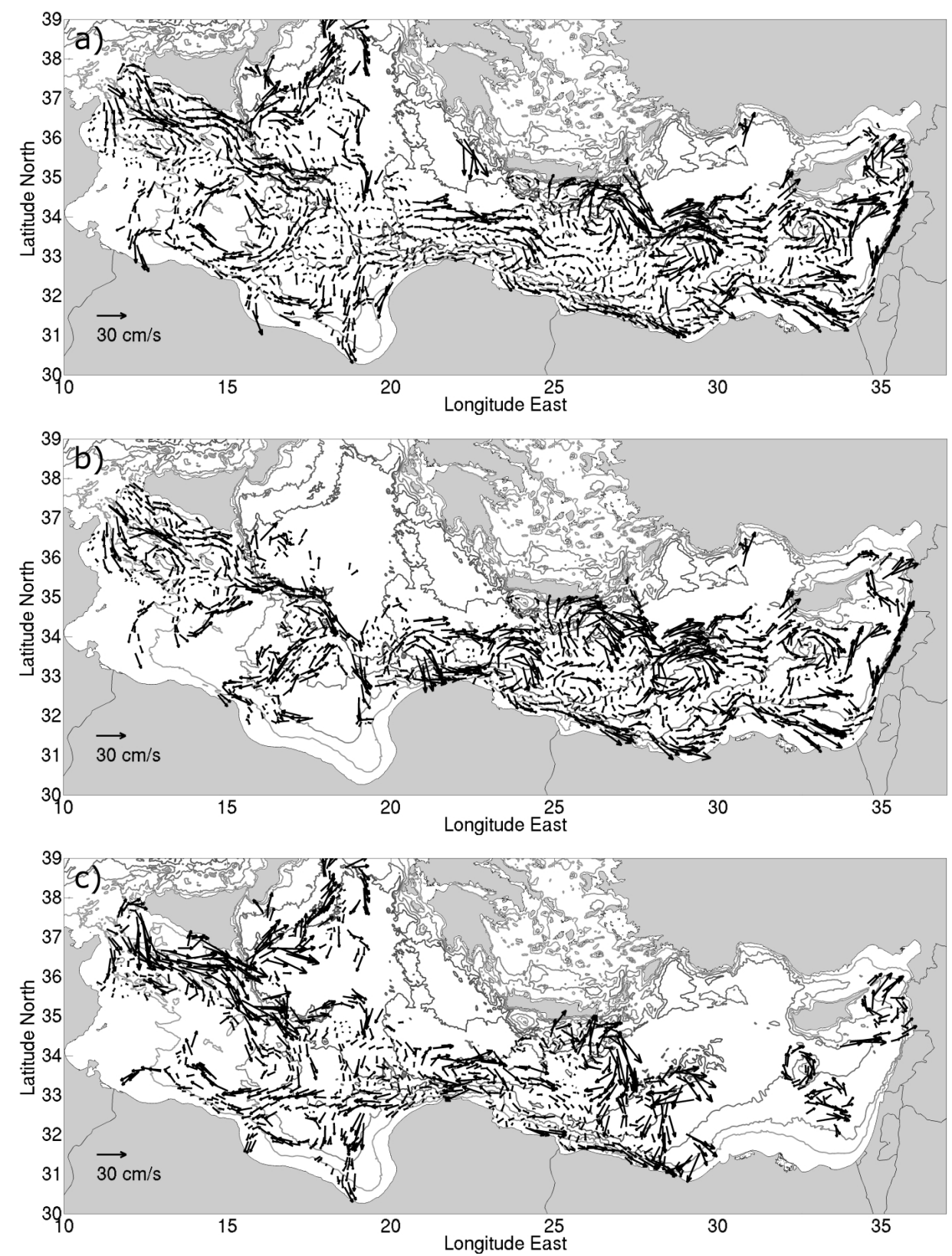

Fig. 8. Mean flow maps obtained from the whole dataset (a), for the extended winter (b) and for the extended summer (c). The mean flow arrows are centred at the centre of mass of the observations in each bin. Data are grouped into $0.5^{\circ} \times 0.5^{\circ}$ bins overlapped by $50 \%$ and results for bins with less than 10 observations and 2 different drifters are not plotted. The undrogued observations with a speed ratio (wind-induced slip/drifter speed) larger than 50\% were not considered in the computation. The $200 \mathrm{~m}, 1000 \mathrm{~m}, 2000 \mathrm{~m}$ and $3000 \mathrm{~m}$ isobaths are represented in grey tones.

Further to the east, the alongslope LEC appears clearly from $\sim 23^{\circ} \mathrm{E}$ all the way to the Middle East. The signatures of all the eddies identified in Fig. 2 and another anticyclonic eddy (south of IE, centred at $\sim 25^{\circ} \mathrm{E}$ ) are clearly visible. In the Levantine sub-basin, the winter mean flow maps display the same features pointed out in the maps obtained using the entire database (Fig. 8a), except for the signature of LE1 and LE2 that are not merged together and the evidence of the eastward alongslope flow between them.
The mean flow during summer (Fig. 8c) is different in the Sicily Channel and in the Ionian. The main feature there is the northernmost branch that splits into two parts when entering the Ionian, south of Sicily. One part goes to the north, reaching $39^{\circ} \mathrm{N}$, before veering to the south. The other part continues to the east and meets the former one in the central Ionian and generates a large anticyclonic feature in the southern Ionian (between $14^{\circ} \mathrm{E}$ and $17^{\circ} \mathrm{E}$ ) extending to the Tunisian slope. The flow in the southern Ionian appears 

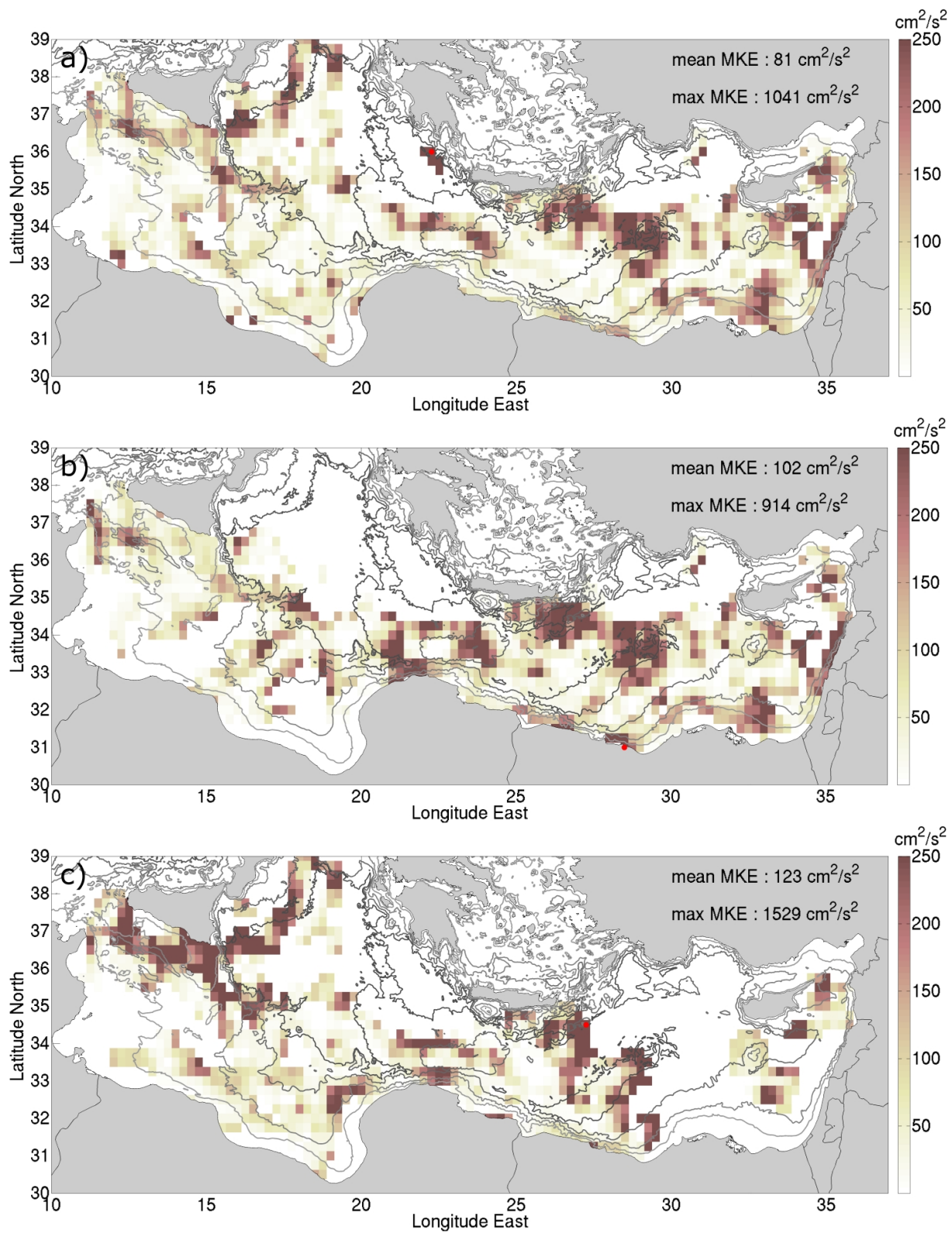

Fig. 9. MKE (saturated at $250 \mathrm{~cm}^{2} / \mathrm{s}^{2}$ ) for the whole dataset (a), for the extended winter (b) and for the extended summer (c). Data are grouped into $0.5^{\circ} \times 0.5^{\circ}$ bins overlapped by $50 \%$ and results for bins with less than 10 observations and 2 different drifters are not plotted. The undrogued observations with a speed ratio (wind-induced slip/drifter speed) larger than 50\% were not considered in the computation. The $200 \mathrm{~m}, 1000 \mathrm{~m}, 2000 \mathrm{~m}$ and $3000 \mathrm{~m}$ isobaths are represented in grey tones. The red dot indicate the absolute maxima.

reversed from eastward to westward and seems to continue westward as far as $12^{\circ} \mathrm{E}$. This is likely related to the change in wind forcing (compare Fig. 3a and b) through direct (Ekman) and indirect (geostrophic adjustment of sea level) wind effects. Indeed, the pseudo Eulerian statistics computed in this area according to the wind regimes (not shown) reveal that during Mistral events the mean flow is everywhere oriented to the southeast and ends on the Libyan coast at $20^{\circ} \mathrm{E}$, while during anti-Mistral regimes the flow is reversed and oriented toward northwest from $11^{\circ} \mathrm{E}$ to $19^{\circ} \mathrm{E}$.
The two anticyclonic circuits in the southern Ionian, as defined in literature and already pointed out in the extended winter, are confirmed. The easternmost one is smaller than in winter and confined more to the slope.

The mean flow pattern in the Cretan Passage (the area between Crete and Libya) is mainly similar to the total average. However, between $20^{\circ} \mathrm{E}$ and $24^{\circ} \mathrm{E}$ the mean flow computed evidenced only one anticyclonic loop. It shows also a westward current alongslope between $20^{\circ} \mathrm{E}$ and $23^{\circ} \mathrm{E}$, corresponding to the southern part of the propagating LE2 and 

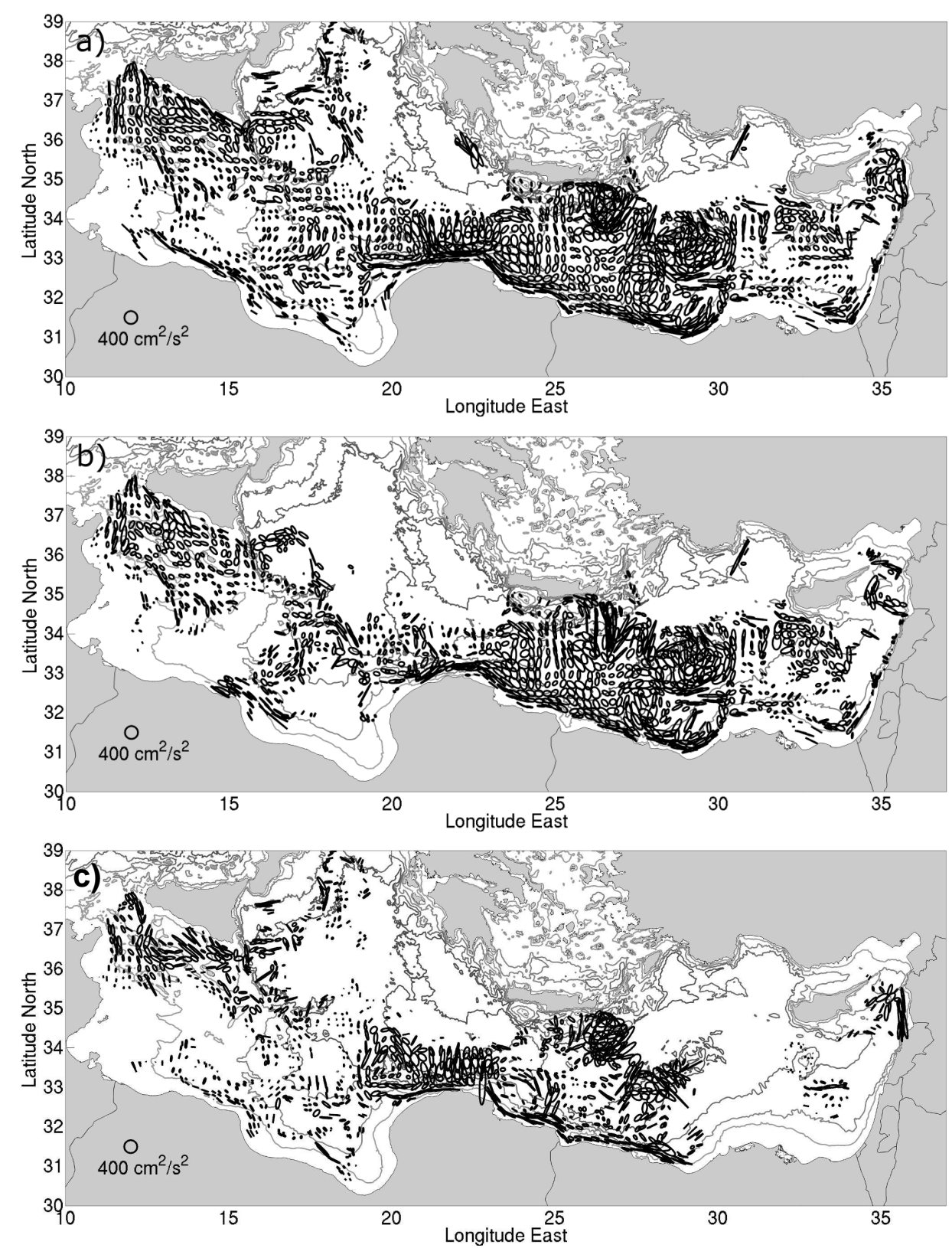

Fig. 10. Variance ellipse maps obtained from the whole dataset (a), for the extended winter (b) and for the extended summer (c). The ellipses are centred at the centre of mass of the observations in each bin. Data are grouped into $0.5^{\circ} \times 0.5^{\circ}$ bins overlapped by $50 \%$ and results for bins with less than 10 observations and 2 different drifters are not plotted. The undrogued observations with a speed ratio (wind-induced slip/drifter speed) larger than $50 \%$ were not considered in the computation. The $200 \mathrm{~m}, 1000 \mathrm{~m}, 2000 \mathrm{~m}$ and $3000 \mathrm{~m}$ isobaths are represented in grey tones.

LE1. One can also note the southward flow south of IE and HTE. As previously said, in summer drifters do not cover the easternmost part of the basin: data are scarce east of $30^{\circ} \mathrm{E}$ and only spotty. ESE and LkE are well identified, as well as a cyclonic loop southeast of ESE (created by the interaction of other anticyclonic eddies seen in satellite thermal images, not shown).
In both extended seasons, MKE (Fig. 9b-c) is maximum in correspondence to the eddies and areas already evidenced in Figs. 8a and 9a. The extended summer appears more energetic than the extended winter. The mean MKE is $123 \mathrm{~cm}^{2} / \mathrm{s}^{2}$ in summer and decreases to about $100 \mathrm{~cm}^{2} / \mathrm{s}^{2}$ in winter. Additionally, the absolute maxima are in correspondence to the LEC near the city of Mersa Matruh in winter $\left(914 \mathrm{~cm}^{2} / \mathrm{s}^{2}\right)$ 

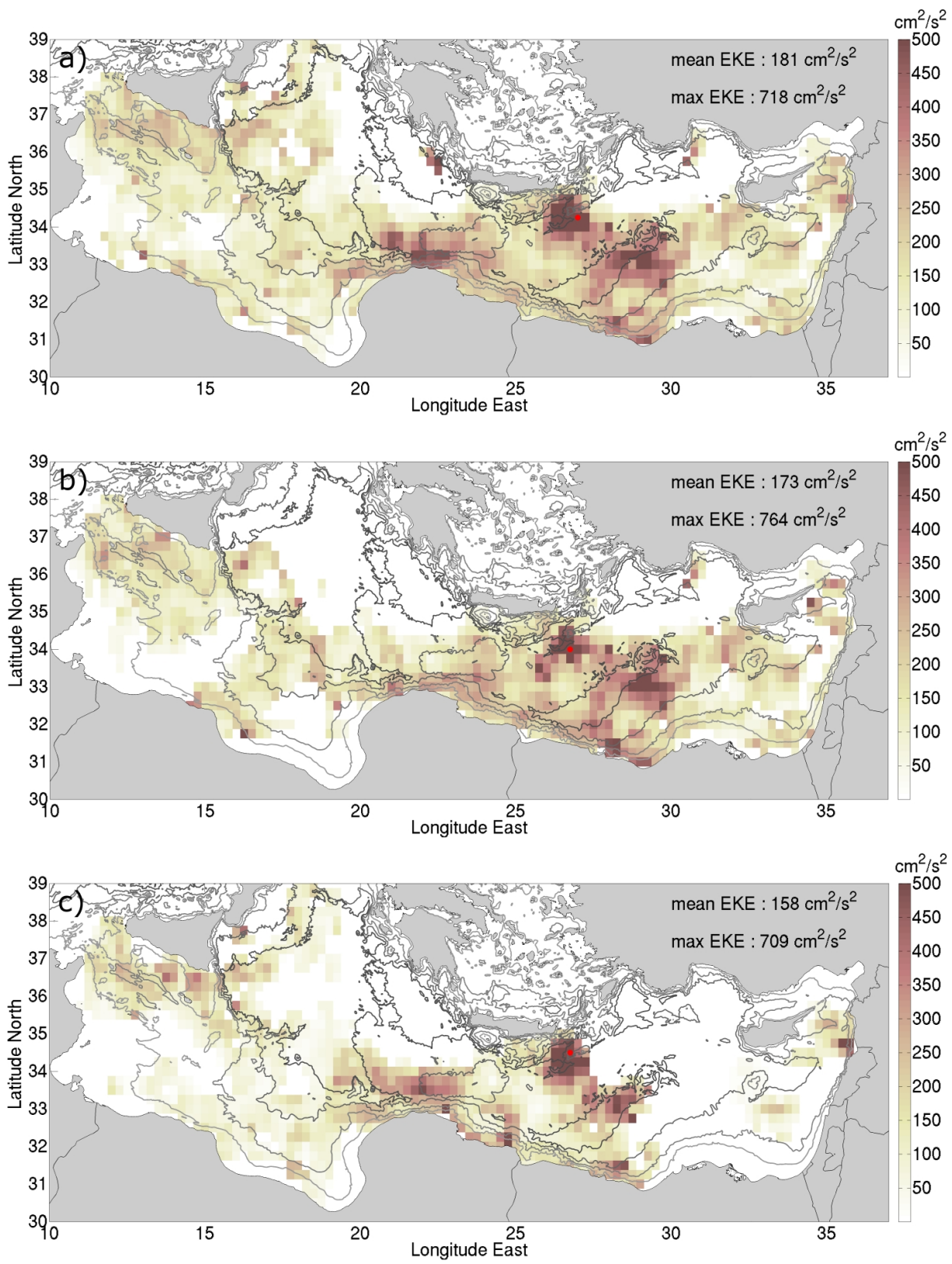

Fig. 11. EKE (saturated at $500 \mathrm{~cm}^{2} / \mathrm{s}^{2}$ ) for the whole dataset (a), for the extended winter (b) and for the extended summer (c). Data are grouped into $0.5^{\circ} \times 0.5^{\circ}$ bins overlapped by $50 \%$ and results for bins with less than 10 observations and 2 different drifters are not plotted. The undrogued observations with a speed ratio (wind-induced slip/drifter speed) larger than 50\% were not considered in the computation. The $200 \mathrm{~m}, 1000 \mathrm{~m}, 2000 \mathrm{~m}$ and $3000 \mathrm{~m}$ isobaths are represented in grey tones. The red dot indicate the absolute maxima.

and by IE in summer $\left(1529 \mathrm{~cm}^{2} / \mathrm{s}^{2}\right)$. The area around Sicily shows a marked increase of MKE in summer with values twice the winter ones. The variance ellipses were calculated for the two extended seasons (Fig. 10b-c) together with the EKE (Fig. 11b-c). A seasonal variability is evident only off Sicily, while elsewhere EKE does not present much seasonal difference. The absolute maxima $\left(764 \mathrm{~cm}^{2} / \mathrm{s}^{2}\right.$ and $709 \mathrm{~cm}^{2} / \mathrm{s}^{2}$ in winter and summer, respectively) occur in correspondence to IE in both extended seasons.

\section{Discussion and conclusions}

Surface drifters were deployed in the eastern basin of the Mediterranean Sea from September 2005 to March 2007, in the framework of the EGITTO/EGYPT programs, to describe its surface circulation patterns. The drifter observations are the first of that kind in that region, especially for the southern parts of the basin where observations were so scarce. Thanks to the high data density the computed mean 
flow maps give robust information on the surface circulation in most of the basin. However the spatio-temporal variability associated with the numerous eddies is so high that it would require trajectories spanning several lifetimes of eddies (i.e., several years) to achieve a representative mean current. Meanwhile caution must be taken when interpreting these results, as for instance off the Libyan slope due to the drifting eddies LE1 and LE2. We compared the amplitudes of the north, south, east and west velocities in the box $20-24^{\circ} \mathrm{E}$ and $32-34.5^{\circ} \mathrm{N}$ : the mean and the maximum velocities of the north and south components are similar to the ones in the east and west directions (the east component is greater, which accounts for the eastward general circulation). This shows that the offshore strong eastward current represented in the mean flow maps (e.g. Fig. 8a) is an artefact, in the same way as statistics can merge two propagating eddies in one single elongated eddy (as seen in Sect. 3.1).

The mean flow maps in the Ionian confirmed the Malanotte-Rizzoli et al. (1997) circulation picture providing additional information in the southern part. The main feature is an eastward flow entering the Sicily Channel and crossing the Ionian in its central part (Fig. 8a). In summer, this flow is stronger (compare Fig. 8b-c) and, east of Sicily, splits in two branches, one of which is northward as far as $39^{\circ} \mathrm{N}$ and then turns anticyclonically and proceeds to the south. This anticyclonic elongated circuit was observed for about 10 years in the 1990s. It has been attributed to interannual variability or decadal variability (e.g. Pinardi et al., 1997; Millot and Taupier-Letage, 2005). Hamad et al. (2005) showed that it vanished from 1998, and our EGITTO/EGYPT drifters data suggest that it re-appeared in 2005-2007. However, the limited temporal extension of the database does not allow to infer any links in these respects. In the southern part of the Sicily Channel, the surface flow is southeastward, following approximately the 200-m isobaths delineating the Tunisian slope, and corresponds to the Atlantic Tunisia Current (Poulain and Zambianchi, 2007) or to the South Tunisia vein (Millot and Taupier-Letage, 2005).

The surface water flows in the southern Ionian along the Libyan slope as confirmed by the flattened variance ellipses (Fig. 10a). However, the flow direction is not definite (eastward from $\sim 12$ to $\sim 17^{\circ} \mathrm{E}$; westward from $\sim 17.5$ to $18.5^{\circ} \mathrm{E}$ ). A seasonal reversal (already pointed out up to $16^{\circ} \mathrm{E}$ by Poulain and Zambianchi, 2007) is evidenced (westward flow in summer and eastward in winter from Tunisia to Cyrenaica).

East of $\sim 20^{\circ} \mathrm{E}$, the main feature is a continuous alongslope cyclonic flow off Africa (the LEC) and the Middle East. This schema generally agrees with the historical diagrams (Nielsen, 1912; Ovchinnikov, 1966; Lacombe and Tchernia, 1972) and there is a specifically good agreement with the most recent one (Millot and Taupier-Letage, 2005).

Part of the surface flow can be deflected offshore by the LEEs interacting with the LEC: on the LEEs northern sides there is locally and temporally a discontinuous eastward off- shore current. Moreover, since eddies are numerous and interact frequently, surface water can be transported seaward around several successive eddies. Such a paddle-wheel effect is well evidenced by the drifters launched in the southern coastal area and then entrained around IE05 (Fig. 5i-1): their trajectories describe several meanders offshore, corresponding to the northern edges of the successive eddies (see Fig. 5 of Taupier-Letage, 2008), and may succeed in reaching the eastern part of the basin (one made it up to Cyprus). The variance ellipses, which are flattened in a north-south direction along $\sim 25^{\circ} \mathrm{E}$ across the whole basin, further support the paddle-wheel effect. But even if this may result in a net eastward transport, this does not constitute a continuous permanent flow, as should be a "Mid Mediterranean Jet". Indeed, only 4 drifters spanned the longitude from $22^{\circ} \mathrm{E}$ to $29^{\circ} \mathrm{E}$. Three of them, after being transported in the central part of the Levantine, ended up on the coast close to the city of Mersa Matruh (see Fig. 5 of Taupier-Letage, 2008) and only one reached Cyprus.

MKE and EKE were computed to point out the most energetic circulation features and the areas characterized by large variability. The energy level of the mean flow is maximum in correspondence to the eddy structures (IE and HTE are the most intense). Here the EKE is also maximum (but generally less intense than MKE), indicating that the fast current here are highly variable. MKE is maximum also all around Sicily during the extended summer, off the Middle East in winter and unevenly alongslope east of $23^{\circ} \mathrm{E}$ during all the year.

Although the EGITTO/EGYPT drifter database represents an unprecedented effort ( 97 drifters in 18 months) for that region, there are still areas and periods where data are scarce. Therefore, it is hoped that Lagrangian observations will be continued in the eastern basin of the Mediterranean Sea as part of scientific and operational oceanography programs, in order improve further our understanding of the circulation in this basin.

\section{Appendix A}

If we denote $\mathrm{u}$ and $\mathrm{v}$ as the zonal and meridional velocity $\left(\mathrm{cm} \mathrm{s}^{-1}\right)$ and use the symbol $<>$ for the time averaging of all the data in a given bin, then the kinetic energy per unit of mass of the mean flow $\left(\mathrm{MKE}, \mathrm{cm}^{2} \mathrm{~s}^{-2}\right)$ is:

$\mathrm{MKE}=\frac{1}{2}\left(<u>^{2}+<v>^{2}\right)$.

The mean kinetic energy per unit of mass of the fluctuating flow, also called mean eddy kinetic energy (EKE, $\left.\mathrm{cm}^{2} \mathrm{~s}^{-2}\right)$, is:

$\mathrm{EKE}=\frac{1}{2}\left(<u^{\prime} u^{\prime}>+<v^{\prime} v^{\prime}>\right)$,

where the prime indicates the residual velocity about the Eulerian mean, for example:

$u^{\prime}=u-<u>$ 
and $\left\langle u^{\prime} u^{\prime}\right\rangle$ and $\left\langle v^{\prime} v^{\prime}\right\rangle$ are the variances in the zonal and meridional direction, respectively. The principal axes of the variance ellipses are computed from the eigenvalues and the eigenvectors of the Eulerian sample covariance matrix (Emery and Thomson, 2004).

Acknowledgements. The authors would like to thanks all the people that helped with the drifter deployments and in particular, Mireno Borghini, Aldo Drago, Ahmed El Gindy, Mikhail Emelianov, Jean-Luc Fuda, Emiliano Gordini, Agusti Julia, Giulio Notarstefano, Gilles Rougier, Mohamed Said, Sarantis Sofianos and George Zodiatis. We are grateful to the captain and crew of R/V Hannibal, R/V OGS-Explora, R/V Urania, R/V L'Atalante, R/V Poseidon, R/V Le Suroit, Princessa Marisa and the Medmar and Grandi Navi Veloci Ferries for their precious help with the drifter deployments. The EGITTO project was partially supported by the Office of Naval Research under grants N000140510281 and N000140610391. The EGYPT project received funding from CNRS/INSU, programs LEFE/IDAO (PATOM) and Groupe de Mission Mercator Coriolis (GMMC), and the Région Provence Alpes Côte d'Azur. We thank the reviewers for their constructive comments on the original version of the manuscript.

Edited by: K. J. Heywood

\section{References}

Alhammoud, B., Béranger, K., Mortier, L., Crépon, M., and Dekeyser, I.: Surface circulation of the Levantine Basin: comparison of model results with observations, Prog. Oceanogr., 66(24), 299-320, 2005.

Beranger, K., Taupier-Letage, I., Alhammoud, B., Lellouche, J. M., Emelianov, M., Mortier, L., and Millot, C.: Analysis of two mesoscale eddies in the southern Ionian and Cretan basins in 2006, Rapp. Comm. Int. Mer Medit., 38 pp., 2007.

Emery, W. J. and Thomson, R. E.: Data Analysis Methods in Physical Oceanography, Elsevier, Amsterdam, 638 pp., 2004.

Fusco, G., Manzella, G. M. R., Cruzado, A., Gacic, M., Gasparini, G. P., Kovacevic, V., Millot, C., Tziavos, C., Velasquez, Z. R., Walne, A., Zervakis, V., and Zodiatis, G.: Variability of mesoscale features in the Mediterranean Sea from XBT data analysis, Ann. Geophys., 21, 21-32, 2003, http://www.ann-geophys.net/21/21/2003/.

Hamad, N., Millot, C., and Taupier-Letage, I.: A new hypothesis about the surface circulation in the eastern basin of the Mediterranean sea, Prog. Oceanogr., 66, 287-298, 2005.

Hamad, N., Millot, C., and Taupier-Letage, I.: The surface circulation in the eastern basin of the Mediterranean Sea, Sci. Mar., 70(3), 457-503, 2006.

Hansen, D. V. and Poulain, P.-M.: Processing of WOCE/TOGA drifter data, J. Atmos. Ocean. Tech., 13, 900-909, 1996.

Korres, G. and Lascaratos, A.: A one-way nested eddy resolving model of the Aegean and Levantine basins: implementation and climatological runs, Ann. Geophys., 21, 205-220, 2003, http://www.ann-geophys.net/21/205/2003/.

Lacombe, H. and Tchernia, P.: Caractères hydrologiques et circulation des eaux en Méditerranée, Mediterranean Sea, edited by: Stanley, D., Dowden, Hutchinson and Ross, Stroudsburg, 25-36, 1972.
Lermusiaux, P. F. J. and Robinson, A. R.: Features of dominant mesoscale variability, circulation patterns and dynamics in the Strait of Sicily, Deep-See Res. Pt. I, 48, 1953-1997, 2001.

Lumpkin, R. and Pazos, M.: Measuring surface currents with Surface Velocity Program drifters: the instrument, its data, and some recent results, Chapter two of Lagrangian Analysis and Prediction of Coastal and Ocean Dynamics (LAPCOD), edited by: Griffa, A., Kirwan, A. D., Mariano, A. J., Ozgokmen, T., and Rossby, T., Cambridge University Press, 39-67, 2007.

Malanotte-Rizzoli, P., Manca, B., Ribera D’Alcala, M., Theocharis, A., Bergamasco, A., Bregant, D., Budillon, G., Civitarese, G., Georgopoulos, D., Michelato, A., Sansone, E., Scarazzato, P., and Souvermezoglou, E.: A synthesis of the Ionian Sea hydrography, circulation and water mass pathway during POEM-Phase I, Prog. Oceanogr., 39, 153-204, 1997.

Manca, B., Burca, M., Giorgetti, A.,Coatanoan, C., Garcia, M.-J., and Iona, A.: Physical and biochemical averaged vertical profiles in the Mediterranean regions: an important tool to trace the climatology of water masses and to validate incoming data from operational oceanography, J. Marine Syst., 48, 83-116, 2004.

Mauerhan, T.: Drifter observations of the Mediterranean Sea surface circulation, Master thesis, Naval Postgraduated School, Monterey, CA, 114 pp., 2004.

Millot, C. and Taupier-Letage, I.: Circulation in the Mediterranean Sea, The Handbook of Environmental Chemistry, Volume K, 2966, doi:10.1007/b107143, May 2005.

Nielsen, J. N.: Hydrography of the Mediterranean and adjacent waters, Rep. Dan. Oceanogr. Exp. Medit., 1, 77-192, 1912.

Ovchinnikov, I. M.: Circulation in the surface and intermediate layer of the Mediterranean, Oceanology, 6, 48-59, 1966.

Pazan, S. E. and Niiler, P. P.: Recovery of near-surface velocity from undrogued drifters, J. Atmos. Ocean. Tech., 18, 476-489, 2001.

Pinardi, N., Korres, G., Lascaratos, A., Roussenov, V., and Stanev, E.: A seasonal model of the Mediterranean Sea general circulation, Geophys. Res. Lett., 24, 425-428, 1997.

Poulain, P.-M., Warn-Varnas, A., and Niiler, P. P.: Near-surface circulation in the Nordic seas as measured by Lagrangian drifters, J. Geophys. Res., 101(C8), 18237-18258, 1996.

Poulain, P.-M.: Adriatic Sea surface circulation as derived from drifter data between 1990 and 1999, J. Marine Syst., 29, 3-32, 2001.

Poulain, P.-M., Barbanti, R., Cecco, R., Fayes, C., Mauri, E., Ursella, L., and Zanasca, P.: Mediterranean surface drifter database: 2 June 1986 to 11 November 1999, Rel. 75/2004/OGA/31, OGS, Trieste, Italy (CDRom and online dataset http://poseidon.ogs.trieste.it/drifter/database_med), 2004.

Poulain, P.-M., Taupier-Letage, I., Gerin, R., Barbanti, R., Deponte, D., and Notarstefano, G.: Oceanographic Cruise EGITTO-1 R/V OGS - EXPLORA 11-18 November 2005 Trieste, Italy to Port Said, Egypt, Cruise Report, Rel. 29/2006/OGA/14, OGS, Trieste, Italy, 2006.

Poulain, P.-M. and Zambianchi, E.: Surface circulation in the central Mediterranean Sea as deduced from Lagrangian drifters in the 1990s, Cont. Shelf Res., 27(7), 981-1001, 2007.

Poulain, P.-M., Gerin, R., Mauri, E., and Pennel, R.: Wind effects on drogued and undrogued drifters in the Eastern Mediterranean, J. Atmos. Ocean. Tech., 26, 1144-1156, 2009. 
Rio, M.-H., Poulain, P.-M., Pascual, A., Mauri, E., Larnicol, G., and Santoleri, R.: A Mean Dynamic topography of the Mediterranean Sea computed from altimetric data, in-situ measurements and a general circulation model, J. Marine Syst., 65, 484-508, 2007.

Robinson, A. R., Golnaraghi, M., Lesile, W. G., Artegiani, A., Hecht, A., Lazzoni, E., Michelato, A., Sansone, E., Theocharis, A., and Unluata, U.: The Eastern Mediterranean general circulation: features, structure and variability, Dynam. Atmos. Oceans, 15, 215-240, 1991.

Robinson, A. R. and Golnaraghi, M.: Circulation and dynamics of the Eastern Mediterranean Sea; Quasi-Synoptic data-driven simulation, Deep-Sea Res., 40(6), 1207-1246, 1993.

Sybrandy, A. L. and Niiler, P. P.: WOCE/TOGA Lagrangian drifter construction manual, Scripps Institution of Oceanography, San Diego, California, SIO REF 91/6, WOCE Report 63, 1991.
Sutyrin, G., Stegner, A., Taupier-Letage, I., and Teinturier, S.: Amplification of a Surface-Intensified Eddy Drift along a Steep Shelf in the Eastern Mediterranean Sea, J. Phys. Oceanogr., 39(7), 1729-1741, 2009.

Taupier-Letage, I. and the EGYPT/EGITTO Teams: New elements on the surface circulation in the eastern basin of the Mediterranean, Rapp. Comm. Int. Mer. Medit., 38 pp., 2007.

Taupier-Letage, I.: On the use of thermal infrared images for circulation studies: applications to the eastern Mediterranean basin, in: Remote sensing of the European Seas, edited by: Barale, V. and Gade, M., Springer Netherlands, 153-164, 2008.

Zervakis, V., Papadoniou, G., Tziavos, C., and Lascaratos, A.: Seasonal variability and geostrophic circulation in the eastern Mediterranean as revealed through a repeated XBT transect, Ann. Geophys., 21, 33-47, 2003, http://www.ann-geophys.net/21/33/2003/. 